\title{
Öğrencilerin Kariyer Planlamalarında Girişimcilik, Profesyonellik ve Liderlik Arzularının Ölçülmesi
}

\author{
Metin ÖNER* ${ }^{*}$ Meltem ONAY** İpek DEVECİ KOCAKOÇ***
}

\begin{abstract}
$\ddot{O} Z$
$B u$ çalışmanın ana amacı Chan vd. (2012) tarafindan geliştirilen "Girişimcilik, Profesyonellik ve Liderlik (EPL)" ölçeğinin Türk ögrenciler için doğrulamasının yapılmasıdır. EPL ölçeği öğrencilerin girişimcilik, profesyonellik ve liderlik bileşenlerine olan arzularını motivasyon, etkinlik ve niyet bazında bağımsız olarak ölçmektedir. EPL ölçeği Kim Yin Chan'den izin alınarak uygulanmış ve anket sorularının cevapları, öğrenci bazında Kim Yin Chan'in vermiş olduğu değerlendirme tablosuna göre toplamsal olarak elde edilmiştir. Bu toplamsal puanlar tüm analizlerde kullanılmıştır. EPL kariyer isteği ölçeği "Motivasyon - Niyet-Etkinlik” olmak üzere ü̧̈ temel faktörden oluşmaktadır. Bu temel faktörlerin "Girişimcilik-Profesyonellik-Liderlik" olmak üzere üçer alt faktörü vardır. EPL ölçeğinin betimsel analizi ve doğrulanması amacı ile anket Türkçe’ye çevrilerek Manisa Celal Bayar Üniversitesi Uygulamalı Bilimler Yüksekokulundaki 903 ögrenciye uygulanmış, iki aşamalı doğrulayıcı faktör analizi ile orijinal ölçeğin Türk öğrencilerine uyumuna bakılmış ve iyi uyum sağlayacak bir şekilde ölçeğin yeniden düzenlenmesi yapılmıştır.
\end{abstract}

Anahtar Kelimeler: Liderlik, Profesyonellik, Girişimcilik, Motivasyon, Etkinlik, Niyet. JEL Sinıflandırması: L26, L29, C38

\section{Measuring Entrepreneurship, Professionalism and Leadership Career Aspiration of Students in Career Planning}

\section{ABSTRACT}

The main purpose of this study is to confirm EPL (Entrepreneurship, professionalism and leadership) scale, which is developed by Chan et.al. (2012) for Turkish students. EPL scale measures students' tendencies towards these components based on their motivation, efficacy and intent. Scale is used by the consent of Kim Yin Chan and results of the surveys are computed in terms of sums of scores as told by the evaluation scheme given by Chan. These summed scores are used in all analyses. EPL scale is composed of three main factors, namely motivation, intent and efficacy. Each main factor has three sub-factors: Entrepreneurship, professionalism and leadership. By a survey study on 903 of Manisa Celal Bayar University students, original EPL scale is examined by second order confirmatory factor analysis (CFA) and re-designed to fit Turkish students.

Key Words: Leadership, Professionalism, Entrepreneurship, Motivation, Efficacy, Intent. JEL Classification: L26, L29, C38

\section{Gİiș}

Bireyler çalışma hayatına ilişkin hedeflerini ve kariyer planlarını gerçekleştirebilmek için hayatlarının çok daha erken dönemlerinde uğraş ve çaba içine girmektedirler. Bu hedefler doğrultusunda hareket eden bireyler eğitimöğretim hayatlarını buna uygun olarak yönlendirmeye başlamaktadırlar. Nitekim

\footnotetext{
*Yrd.Doç.Dr., Manisa Celal Bayar Üniversitesi, Uygulamalı Bilimler Yüksekokulu, metin.oner@cbu.edu.tr

** Prof.Dr., Manisa Celal Bayar Üniversitesi, Uygulamalı Bilimler Yüksekokulu, meltemonay@gmail.com

**** Prof.Dr., Dokuz Eylül Üniversitesi, İktisadi ve İdari Bilimler Fakültesi, ipek.deveci@deu.edu.tr
} 
kendilerinde eksik gördükleri yönlerini gerekli eğitimlerle telafi etmeye çabalamakta, güçlü buldukları yönlerini (yetenek ve becerilerini) daha da geliştirmeye çalışmaktadırlar.

Günümüzde çıkan iş ilanlarına göz atıldığında, bu ilanların pek çoğunda bireylerde tek bir özellikten ziyade çok sayıda özelliğin, çok değişik bilgi ve becerinin arandığg görülmektedir. Bir elemandan hem çok çeşitli teknik bilgi, hem de bazı sosyal özelliklere sahip olması istenmektedir. Günümüzde bu durum, kariyer sahibi olmak isteyen kişilerde yetenekle bilginin bir arada yoğrulması gerektiğini göstermekte, bireylerin kariyer gelişimi için sadece tek bir konuda uzmanlaşmanın yeterli olamayacağı gerçeğini yansıtmaktadır.

Kariyer kavramı, Türk Dil Kurumu Sözlüğünde, "bir meslekte zaman ve çalışmayla elde edilen aşama, başarı ve uzmanlık" olarak tanımlanmaktadır. Bu tanımdan da yola çıkarak kariyerin, genellikle meslekte yükselme, belirli bir statü elde etme, ilerleme ve tercih edilen bir mesleğe sahibi olma seklinde ele alındığ söylenebilir (Sabuncuoğlu, 2005;168).

$\mathrm{Bu}$ çalışmadaki temel amaç, Chan vd. (2012) tarafından geliştirilen "Girişimcilik, Profesyonellik ve Liderlik (EPL)" ölçeğinin Türk öğrenciler için doğrulamasının yapılmasıdır. Bu ölçek öğrencilerin girişimcilik, profesyonellik ve liderlik bileşenlerine olan arzularını motivasyon, etkinlik ve niyet bazında bağımsız olarak ölçmek için tasarlanmıştır. EPL kariyer isteği ölçeği "Motivasyon - Niyet - Etkinlik" olmak üzere üç temel faktörden oluşmaktadır. Bu temel faktörlerin "Girişimcilik - Profesyonellik - Liderlik" olmak üzere üçer alt faktörü vardır. Çalışmada ölçeğin doğrulanması amacıyla anket Manisa Celal Bayar Üniversitesi Uygulamalı Bilimler Yüksekokulundaki 903 öğrenciye uygulanmış, iki aşamalı doğrulayıcı faktör analizi ile orijinal ölçeğin Türk öğrencilerine uyumuna bakılmış ve iyi uyum sağlayacak bir şekilde ölçeğin yeniden düzenlenmesi yapılarak raporlanmıştır.

EPL ölçeği bireylerin çoklu kariyer alanlarında motivasyon ve kapasitelerini, liderlik, profesyonellik ve girişimcilik temelinde dikkate almaktadır. $\mathrm{Bu}$ nedenle EPL ölçeğinde geçen ve yönetim yazınında çokça tartışılmış liderlik, girişimcilik ve profesyonellik kavramlarına ayrı bir bölümde kısaca değinmek yararlı olacaktır.

\section{KAVRAMSAL ÇERÇEVE}

Eski bir kavram olan liderlik, pek çok araştırmacı tarafından çok değişik yönleriyle incelenmiş, özellikleri ile ilgili pek çok tartışma yapılmıştır (Rost (1993), Barker (2002), Yukl (2002:3), Marques ve Dhiman (2017)). Yönetim yazınında yer alan "yöneticilik" ve "liderlik" kavramları arasındaki farkı bir kez daha vurgulamak yararlı olacaktır. Yöneticilik, işletmeyi önceden belirlenen ilke, kural ve hedefler doğrultusunda sevk ve idare etmek anlamında kullanılırken, liderlik, işletme için önceden belirlenen ilke, kural ve hedefleri geliştiren, yeni ilke, kural ve hedef koyan anlamındadır. Yönetim yazınında birçok liderlik 
türünden söz edilmektedir. Liderlik ile performans arasındaki ilişki için üzerinde mutabakat sağlanan yargı şudur: İşletmede çalışan bir bireyin ne tür "liderlik özelliklerine" sahip olduğu doğru tespit edebilirlerse ve doğru yönde kullanılabilirse bireyin göstermiş olduğu performansın ve işletmenin bütününe ait performansin o denli etkin olarak yükseleceği gerçeğidir.

Girişimcilik, liderliğe göre daha yeni bir kavramdır. Literatürde değişik yazarlar tarafından pek çok farklı tanım yapılmıştır (Onuoha G. (2007), Sexton D. ve Bowman N. (1985), Hisrich, R.D. (1990)). Peter Drucker (1970) girişimciliği "risk almak" olarak tanımlarken, Cogliser ve Brigham (2004), liderlik ve girişimcilik kavramları arasındaki ilişkiyi incelemişlerdir. İş hayatı için öncelikle bireyin kendisini çalıştığ alana uygun olarak geliştirmesi gereklidir. Daha sonra birey kazandığı bilgi ve tecrübeyi sahip olduğu "girişimci" özellikleriyle bütünleştirebildiği ölçüde performans başarısı, iş doyumu sağlayacaktır. Bir anlamda girişimcilik kişinin içsel olarak sahip olduğu yetenek ve cesaretle bilginin ve tecrübenin gösterilmesi ve ileri götürülmesidir. Birey kariyer yolculuğunda yeteneği olmadığı işte yeterli performansı gösteremediğinde, çalıştığ 1 işinde mutsuz ve doyumsuz olacaktır. Sonuçta çalıştığ 1 işletmeye karşı aidiyet ve bağlılık zayıflayacak, çok kolaylıkla iş değiştirme, devamsızlık gibi istenmeyen davranış şekillerine başvuracaktır. Günümüz dünyasında yönetsel niteliklere sahip girişimcilere ve girişimci niteliklerine sahip yöneticilere sahip olan işletmelerin, küreselleşen dünyada önemli bir avantaj yakaladıkları söylenebilir (Nişancı vd. 2015).

Liderlik ve girişimcilik kavramlarıyla yakından bağlantılı diğer bir kavram ise profesyonelliktir. Profesyonellik üstünde çok tartışılan bir kavramdır (Downie, 1990). Profesyonellik sadece bir takım elbise giymek, bir işi yerine getirmek ya da evrak çantası taşımak değil, çalıştığı işte sorumluluk, mantık, güvenilirlik ve mükemmellik içinde davranmaktır. Etkin bir şekilde iletişim kurmak ve her durumda verimli olmanın bir yolunu bulmaktır. Hambrick ve Mason'ın (1984) yapmış oldukları araştırma yönetim bilimleri yazınında "profesyonel yöneticiler" ile ilgili ilk ciddi çalışmadır. Zaman içerisinde konuyu değişik boyutlardan hareketle inceleyen önemli çalışmalar yapılmıştır (Khurana, 2001; Taş ve Çavuş, 2010).

Bu kavramlar ikişerli olarak yazındaki çeşitli çalışmalarda yer almış olsalar da, Türkçe veya İngilizce olarak "girişimcilik, profesyonelik ve liderlik" anahtar sözcükleriyle tarandığında, Chan ve diğerlerinin çalışmaları haricinde bu kavramların üçünün birlikte incelendiği çalışmaya rastlanmamaktadır. Bu üç kavramın birbiri ile ilişkili olduğunun incelenmesi için daha çok çalışmaya ihtiyaç vardır. Bu makale, EPL ölçeğinin doğrulanması yolu ile bu konuda yapılabilecek çalışmalar için yol gösterici olmayı amaçlamaktadır. 


\section{ARAŞTIRMANIN YÖNTEMI}

EPL (E: Entrepreneurship-Girişimcilik, P: ProfessionalismProfesyonellik, L: Leadership-Liderlik) öğrenci kariyer arzusu ölçeği, Chan ve diğerleri (2012) tarafından geliştirilmiştir. Kanter (1989)'ın üç temel kariyer formu yapısını temel almışlar, fakat öğrencilerin bu kariyerlerin sadece birini değil, bir bileşimini seçebileceği düşüncesiyle, çoklu kariyer uzayı adını verdikleri bir yapıya göre çalışmalarını tasarlamışlardır. Anketi 2012'de Singapur'daki Nanyang Technological University'de okuyan 10326 öğrenci üzerinde geliştirilmeye başlanmışlardır. Daha sonra bazı ufak düzenlemelerle son halini almıştır. EPL ölçeği, bireyleri, yani öğrencileri çoklu kariyer alanlarında motivasyonları ve kapasiteleri olan bireyler olarak görmektedir. Öğrenciler tek bir kariyer yolu seçmektense, örneğin "profesyonel bir lider olmak istiyorum" veya "girişimci bir profesyonel olmak istiyorum" veya "girişimci bir lider olmak istiyorum" gibi farklı bileşimlerden birini tercih edebilmektedir. Ölçeğin temel varsayımı, öğrencilerin kariyer yönelimlerinin üç temel bileşeni olduğudur: girişimcilik, profesyonellik ve liderlik. EPL ölçeği ile öğrencilerin bu bileşenlere olan arzuları motivasyon, etkinlik ve niyet bazında bağımsız olarak ölçülmektedir. Tüm bu varsayımlar 1şığında, ölçek günümüzün çoklu uzmanlık gerektiren mesleklerin artması gerçeğini de yansıtmakta ve ölçmektedir (Chan vd, 2012).

EPL Ölçeği 3 temel faktörden oluşmaktadır.

- Motivasyon: Girişimci, profesyonel ve lider olma motivasyonlarını ölçen 5'li Likert tipi 27 soruluk bir ölçektir.

- Niyet: Mezuniyetten sonra girişimci, profesyonel ve liderlik kariyerini seçme niyetini ifade eden 5'li Likert tipi 11 soruluk bir ölçektir.

- Etkinlik: Belirli bir yetenek ve faaliyetler setindeki görevleri başarmakla ilgili "hiç emin değilim" den "kesinlikle eminim" e kadar 5'li Likert tipi ölçekte değerlendirilen 19 soruluk bir ölçektir.

Ölçekte temel faktörler olan motivasyon, niyet ve etkinlik faktörlerinin her birinin üçer alt faktörü vardır: Girişimcilik, Profesyonellik ve liderlik. Bu çalışma, ölçeğin dilimize uyarlanması amacıyla yapılmış betimsel bir çalışmadır. Ölçeğin son hali Kim Yin Chan'den e-posta ile istenmiş, izin alınarak Türkçeleştirilmiş ve uygulanmıştır. Anket sorularının cevapları, öğrenci bazında Kim Yin Chan'in vermiş olduğu değerlendirme tablosuna göre toplamsal olarak elde edilmiş ve bu toplamsal puanlar tüm analizlerde kullanılmıştır.

$\mathrm{Bu}$ çalışmanın temel amacı ölçeğin Türk öğrenciler için doğrulanmasıdır. Orijinal anket, Singapur'daki bir üniversitenin öğrencileri üzerinde yapılmıştır. Toplam 10.326 öğrenciden \%55,6's1 erkek, \%43,3'ü k1z öğrencilerden oluşmaktadır. Bu öğrencilerin \% 64,7'si Singapurlu, \%28,5'u başka ülkelerden gelmiştir. Lisans öğrencileri (\%81,7) iken, yüksek lisan öğrenciler ise \%18,3'dür. Ögrrencilerin \%50'si mühendislikte, \%17,6's1 sanatta, \%16,4'ü sosyal bilimlerde, \%16's1 işletmede okumaktadır (Chan vd., 2012). Bu makalede analiz edilen 
anket, Manisa Celal Bayar Üniversitesi Uygulamalı Bilimler Yüksekokulu'ndaki 903 öğrenciye uygulanmıştır. Örneklem için tüm öğrencilere ulaşılmak amaçlanmış, ancak hepsinden geri dönüş sağlanamamıştır. Toplam kayıtlı 1465 öğrenciden 903 öğrenciye anket uygulanarak \%62'lik örnekleme oranına ulaşılmıştır. Araştırmanın başlangıç aşaması, Singapur'daki araştırmada olduğu gibi Manisa Celal Bayar Üniversitesindeki tüm akademik birimler için kurgulanmış olmasına rağmen, bütün üniversiteye gerekli anket dağılımı sağlanamamıştır. Bu durum araştırmanın sınırlarından biridir.

Öner vd. (2016)'nin çalışmasında anketin ön analizleri yapılmıştır. Çalışmalarında ankete katılan UBYO öğrencilerinin cinsiyet, sınıf, bölüm, annebabanın çalışma durumu, öğrencinin daha önce bir sosyal sorumluluk projesinde yer alıp almaması ve daha önceden herhangi bir girişimcilik faaliyetinde bulunup bulunmamasının EPL ölçeğindeki alt faktörler açısından fark gösterip göstermedikleri tek değişkenli istatistiksel yöntemlerle incelenmiş ve yorumlanmıştır. $\mathrm{Bu}$ nedenle bu makalede temel istatistiksel analizlerin sonuçlarına yer verilmemiştir.

Bu çalışmada iki aşamalı doğrulayıcı faktör analizi ile orijinal ölçeğin Türk öğrencilerine uyumuna bakılmış ve iyi uyum sağlayacak bir şekilde ölçeğin yeniden düzenlenmesi yapılarak raporlanmıştır.

\section{ARAŞTIRMA BULGULARI}

Araştırma bulguları birkaç bölümden oluşmaktadır. İlk olarak araştırmaya katılan öğrencilerin demografik özellikleri kısaca özetlenmiştir. Daha sonra ise doğrulayıcı faktör analizinin sonuçları raporlanmış ve yorumlanmıştır.

\section{A. Demografik Göstergeler}

Ankete katılan 903 öğrencinin \%61'i kız (548), \%39’u erkek (352)'dir. Aynı öğrencilerin yaşları arasında yapılan dağılıma bakıldığında; öğrencilerin $\% 75$ 'ten fazlasının 22 ve altı yaşlarda olduğu, \%10 kadarının 24 yaş üstünde olduğu tespit edilmiştir.

Öğrencilerin okudukları bölümlere göre dağılımlarına bakıldığında, \%40'ının "Bankacılık ve Finans Bölümü” örgün öğretimde, \%28'inin "Uluslararası Ticaret Bölümü'nde, \%32'sinin de "Bankacılık ve Finans Bölümü" ikinci öğretimde okumakta oldukları görülmektedir. Öğrencilerin \%26's1 "birinci sınıf", \%25'i "ikinci sinıf”, \%22'si "üçüncü sınıf”, \%27'si ise "dördüncü sınıf" öğrencisidir.

Öğrencilerin "girişimcilik, profesyonellik, liderlik" özelliklerinin gelişiminde anne ve babalarının çalışma durumlarının etkili olabileceği düşünüldüğu için, anket formunda buna yönelik sorular konulmuştur. Buna göre; öğrencilerin \%77'sinin annesi çalışmamaktadır. Bunun tam tersi olarak babalarının \%69'u çalışmaktadır. 
Şekil 1: Orijinal Model ve Doğrulanan Modeldeki Sorular

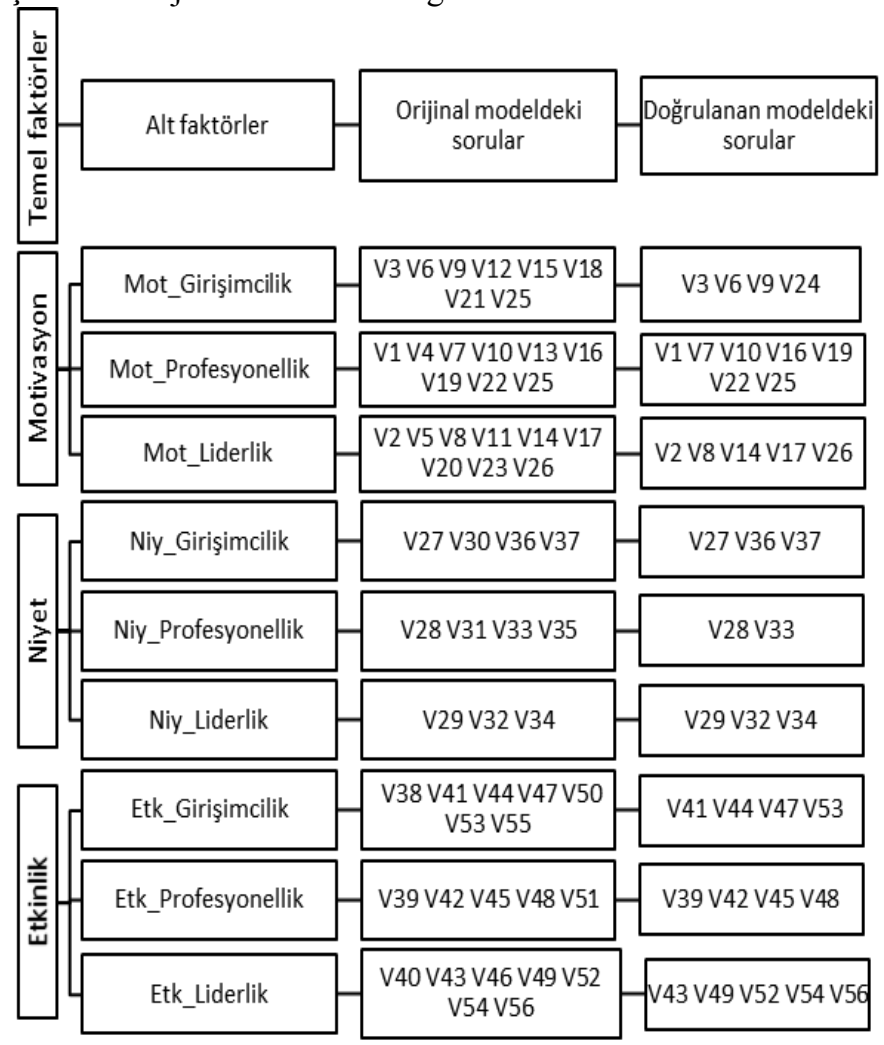

\section{B. Analiz ve Değerlendirme}

Orijinal ölçeğin UBYO öğrencileri için doğrulanması amacıyla, iki aşamalı doğrulayıcı faktör analizi (DFA) uygulanmıştır. Bazı sorular anket dışı kalmasına rağmen EPL Ölçeği temel olarak UBYO öğrencileri için doğrulanmıştır. LISREL programı kullanılarak alt faktörlerin ana faktörlerle ve ana faktörlerin birbirleri ile olan ilişkileri araştırılmıştır. Sonuç olarak orijinal EPL ölçeğinin Türk öğrenciler içinde uygulanabilecek bir şekli elde edilmiştir. Doğrulayıcı faktör analizi sonucunda bazı sorular doğrulanamayıp çıkarılmış ve ankette kalan sorular Şekil 1'de gösterilmiştir. Soruların bazıları ters kodludur ve ekte verilen soru formu üzerinde belirtilmiştir.

Daha önce de belirtildiği gibi, temel faktörlerin (motivasyon, niyet, etkinlik) her birinin 3'er alt faktörü vardır: Profesyonellik, liderlik, ve girişimcilik. Orijinal ankette ve doğrulanan ankette her bir alt faktörü oluşturan sorular ile temel ve alt faktörlerin ilişkisi Şekil 1'de görülmektedir. UBYO öğrencileri için doğrulanan faktör yapısı ise Şekil 2'de gösterilmiştir. 
Şekil 2: İki Aşamalı DFA Modeli

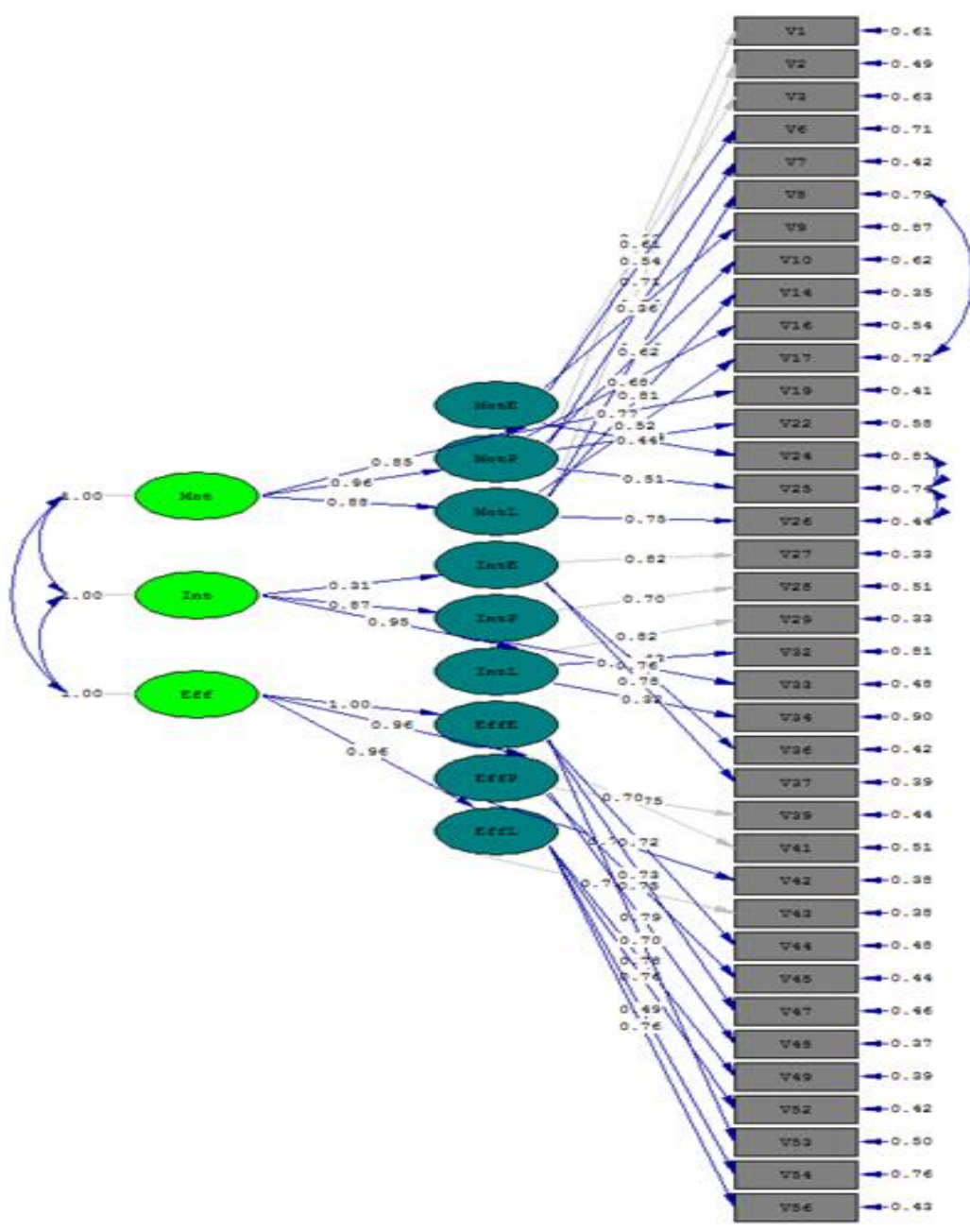

Chi-square=2799.23, df=614, p-value=0.00000, RMSEA=0.063 
Şekil 3: İkinci Dereceden Model

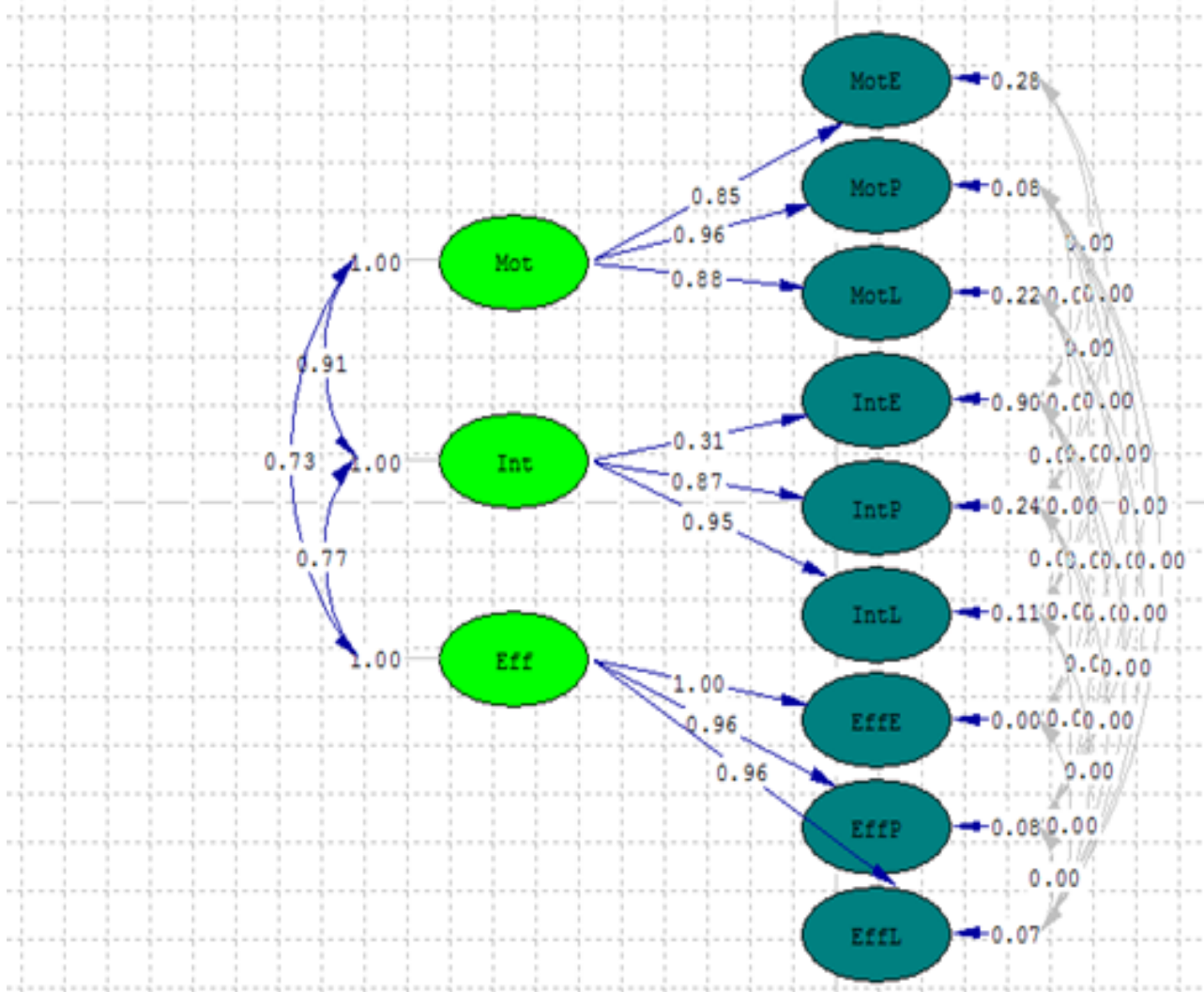

Chi-Square $=2799.23, . d f=614, . P$-value $=0.00000, \quad$ RMSEA $=0.063$

İki aşamalı DFA modelinin geneline bakıldığında, uyum iyiliği istatistiklerinin kabul edilebilir seviyede olduğu görülmektedir. Ki-kare/serbestlik derecesi oranı 5 'in altındadır ve RMSEA değeri 0.063 tür. Modelin karşılaştırmalı uyum indisi $(\mathrm{CFI})=0.84$ ve uyum iyiliği indisi $(\mathrm{GFI})=0.81$ olarak elde edilmektedir. Bu büyüklük ve karmaşıklıktaki bir model için bu değerler kabul edilebilir bir modele işaret etmektedir.

Şekil 2'deki DFA modelinin birinci derecesi (sorular ile alt faktörlerin ilişkileri) incelendiğinde, tüm sorular oldukça yüksek faktör yükleriyle alt faktörlere yüklenmişlerdir. Bu şeklin yorumlanması çok karmaşık olduğundan ikinci derece model (alt faktörlerin temel faktörler ile ilişkisi) Şekil 3'te verilmiştir. İkinci dereceden modele bakıldığında ise, alt faktörlerin temel faktörleri açıklama durumları görülebilir. Buna göre motivasyonun her üç alt faktörünün de motivasyon ile oldukça yüksek ilişkisi vardır. $(0,85 ; 0,96 ; 0,88)$. Niyet boyutuna bakıldığında profesyonellik ve liderlik ilişkisinin girişimcilikten 
daha yüksek olduğu görülmektedir $(0,31 ; 0,87 ; 0,95)$. Etkinlik boyutuna bakıldığında her üç alt faktörün motivasyon ile oldukça yüksek ilişkisi vardır $(1,00 ; 0,96 ; 0,96)$.

Şekil 3'de görüldüğü gibi bütün öğrencilerin liderlik, girişimcilik ve profesyonellik ile ilgili motivasyonları bir faktör oluşturabilmektedir. Aynı şekilde mezuniyet sonrası öğrencilerin profesyonellik, girişimcilik ve lider olma niyetleri de bir faktör oluşturmaktadır. Son olarak bütün öğrencilerin lider olma, profesyonellik, girişimcilik ile ilgili etkinliklerde kendilerini yeterli görme durumları da bir etkinlik faktörü oluşturmaktadır.

Tablo 1: Tüm Alt Faktörlerin ve Ana Faktörlerin Birbirleriyle Olan Korelasyonları

\begin{tabular}{|l|c|c|c|c|c|c|c|c|c|c|c|c|}
\hline & MotE & MotP & MotL & IntE & IntP & IntL & EffE & EffP & EffL & Mot & Int & Eff \\
\hline MotE & 1 & & & & & & & & & & & \\
\hline MotP & 0.82 & 1 & & & & & & & & & & \\
\hline MotL & 0.82 & 0.84 & 1 & & & & & & & & & \\
\hline IntE & 0.34 & 0.34 & 0.34 & 1 & & & & & & & & \\
\hline IntP & 0.69 & 0.7 & 0.7 & 0.34 & 1 & & & & & & & \\
\hline IntL & 0.8 & 0.81 & 0.81 & 0.4 & 0.81 & 1 & & & & & & \\
\hline EffE & 0.68 & 0.69 & 0.69 & 0.31 & 0.64 & 0.75 & 1 & & & & & \\
\hline EffP & 0.65 & 0.66 & 0.66 & 0.3 & 0.62 & 0.72 & 0.95 & 1 & & & & \\
\hline EffL & 0.65 & 0.66 & 0.66 & 0.3 & 0.62 & 0.72 & 0.95 & 0.92 & 1 & & & \\
\hline Mot & 0.9 & 0.91 & 0.91 & 0.38 & 0.77 & 0.89 & 0.75 & 0.73 & 0.73 & 1 & & \\
\hline Int & 0.83 & 0.84 & 0.84 & 0.41 & 0.83 & 0.97 & 0.77 & 0.74 & 0.74 & 0.92 & 1 & \\
\hline Eff & 0.68 & 0.69 & 0.69 & 0.32 & 0.65 & 0.75 & 0.99 & 0.96 & 0.96 & 0.76 & 0.77 & 1 \\
\hline
\end{tabular}

Temel faktörlerin birbirleri ile korelasyonlarına bakıldığında (Şekil 3, en soldaki oklarda) motivasyon ve niyetin yüksek derecede $(0,91)$ ilişkili olduğu; motivasyon ve etkinliğin orta derece $(0,73)$ ve niyet ve etkinliğin yine orta derece $(0,77)$ ilişkili olduğu görülmektedir. Tüm alt faktörlerin birbirleriyle olan korelasyonları ise Tablo 1'de gösterilmiştir. Korelasyonların tamamı istatistiksel olarak anlamlıdır. Tablo 1'den görüleceği üzere, tüm alt faktörler de birbirleriyle ilişkilidir. Motivasyonun alt faktörleri ile niyetin alt faktörlerinin ilişkisinin daha yüksek olduğu görülmektedir.

\section{SONUÇ VE DEĞERLENDİRME}

Üniversite öğrencilerinin en önemli hedeflerinden biri gelecekte iyi bir kariyere sahip olmaktır. Kariyer elde etmenin yolu bireyin okuduğu alanda gerekli eğitimleri alıp, mesleki ve bireysel açıdan kendisini geliştirmesine bağlıdır. Bu bağlamda kişinin mesleki kariyeri hangi alanda olursa olsun iş hayatı ile başladığı düşünülse de, aslında üniversitede seçmiş olduğu bölümün çıktıları ile doğrudan ilgilidir. 
Bir öğrenci gelecek ile ilgili planlarını, kariyer hedeflerini yapıyorsa, kendisini yakından tanıması, kişisel özelliklerini ve yetkinliklerini belirlemesi, kendini geliştireceğine inandığı alanlara yönelmesi, gerekli gördüğü takdirde doğru uzmanlardan ve eğitmenlerden destek alması ve mesleki açıdan daha profesyonel bir tutum sergileyecek faaliyetlere çok daha erken bir dönemde başlaması gereklidir.

EPL ölçeği, bu amaçla öğrencileri değerlendiren ve yıllar içinde geliştirilmeye devam eden bir ölçektir. Bu ölçeğin Türk öğrencilere uyarlanması önemlidir. Yapılan analizler sonucunda, ölçeğin hem Türkçe literatüre tanıtılması, hem de sınırlı bir öğrenci örneği için doğrulanması amaçlanmıştır. İki aşamalı doğrulayıcı faktör analizi ile, orijinal ölçekteki bazı sorular çıkarılarak ve tekrar düzenlenerek doğrulanmış bir anket formu oluşturulmuştur. Yapılan bu araştırma ve yaygınlaştırılması, öğrencilerimizin 'liderlik, girişimcilik, profesyonellik' gibi çok önemli kişisel özelliklerini geliştirmede seçtikleri bölümün ne derece etkili olduğunu göstermesi açısından da önemlidir.

Araştırma verilerinin sonuçları üniversite öğrencilerinin kendi kariyer planlamaları açısından yaşamlarını etkileyen üç temel kişisel ve yönetsel becerinin (girişimcilik, profesyonellik ve liderlik) okul hayatı süresince geliştirilmesinin olumlu etkilerini göstermektedir.

Şekil 3 ve Tablo 1'de verilen sonuçlar dikkate alındığında aşağıdaki çıkarımlara ulaşmak mümkün olmuştur:

1. Öğrencilerin motivasyonu yüksek tutulursa, onların profesyonel lider ve girişimcilik özelliklerini geliştirme niyetleri de bir o kadar yükseltilebilir.

2. Öğrencilerin motivasyonu yüksek tutulursa, kendilerini daha yeterli görmeye başlayacaklardır ki bu durum daha 'sonuç odaklı' çalışmalar yapmayı öğrenmelerine yardımcı olacaktır.

3. Öğrencilerin profesyonellik, liderlik ve girişimcilik konusunda daha başarılı olmaya yönelik niyetleri arttıkça, kendilerini daha yetkin görmeye başlayacaklardır.

4. Öğrencilere üniversiteye başladıkları andan itibaren yapılacak olan 'kişisel yetkinlik anketleri' onların hangi özelliklerinin eksik ya da güçlü olduğu konusunda okul yönetimine ipuçları verecektir. $\mathrm{Bu}$ doğrultuda, okul yönetimleri öğrencileri belirli gruplara (profesyonel olarak çalışmak isteyenler, girişimci olmak isteyenler, liderlik özelliklerini geliştirmek isteyenler vb.) ayırarak, birinci sinıftan dördüncü sinıfa kadar öğrenci kariyer planlamalarının yapılmasına yardımcı olabilecektir. Bu tür bir araştırmanın yapılması sonucunda, ülkemizde istihdam edilecek yeni mezun öğrencilerin de mesleki hayatlarının ilk aşamasında daha motivasyonlu, daha istekli ve daha bilgili adımlar ile ilerlemelerine yardımcı olunmuş olacaktır. 


\section{KAYNAKÇA}

Barker, R. A. (2002). On the nature of Leadership. Lanham, MD: University Press of America.

Chan, K.Y., Ho, M.H.R., Chernyshenko, O.S., Bedford, O., Uy, M.A., Gomulya, D., Sam, Y.L., Phan, W.M.J. (2012). Entrepreneurship, professionalism, leadership: A framework and measure for understanding boundaryless careers. Journal of Vocational Behavior, Vol:81, No:1, 73-88.

Cogliser, C.C., Brigham, K.H. (2004). The intersection of leadership and entrepreneurship: Mutual lessons to be learned. The Leadership Quarterly, 15, 771-799.

Downie, R. (1990). Professions and professionalism, Journal of Philosophy of Education, Vol:24, Issue 2, 147-159.

Hambric, D.C., Mason, P. A., (1984). Upper Echelons: The Organization As A Reflection Of İts Top Managers. Academy of Management Review, Vol:9, No:2, 193-206.

Hisrich, R. D., Peters, M. P. (1989). Entrepreneurship: Starting, Developing, and Managing a New Enterprise. Homewood, IL: BPI, Irwin.

Kanter, R. M. (1989). Careers and the wealth of nations: A macro-perspective on the structure and implications of career forms. In M. Arthur, D. Hall, B. Lawrence (Eds.), Handbook of career theory (pp. 506-522). Cambridge, UK: Cambridge University Press.

Khurana, R. (2001). Finding the right CEO: Why boards often make poor choices. MIT Sloan Management Review, Vol:43, No:1, 91-95.

Marques, J., Dhiman, S. (Eds.). (2017). Leadership Today: Practices for Personal and Professional Performance. Springer.

Onuoha G. (2007). Entrepreneurship. AIST International Journal, 10, s.20-32.

Öner, M., Onay, M., Kocakoç, İ.D. (2016). Girişimcilik, Profesyonellik ve Liderlik Ölçeğinin CBÜ Uygulamalı Bilimler Yüksekokulu Öğrencileri Üzerinde İncelenmesi”, IMCOFE2016, International Multidisciplinary Congress Of Eurasia 2016, Odessa, 11-13 Temmuz. IMCOFE Proceedings Volume-2, 69-76.

Rost, J. C. (1993). Leadership for the twenty-first century. Praeger, Westport, Connecticut, London, 1993.

Sabuncuoğlu, Z. (2005). Insan Kaynakları Yönetimi. Bursa, Alfa Yayınları.

Taş, A., Çavuş, M.F. (2010). Türkiye'deki Profesyonel Yöneticiler Üzerine Bir inceleme: Nasıl Seçiliyorlar? Hangi Özellikleri Ön Plana Çıkıyor? Hangi Yetkilerle Donatılıyorlar? Çukurova Üniversitesi Sosyal Bilimler Enstitüsü Dergisi, Cilt 19, Sayı:1, 185-201.

Yukl, G. (2002). Leadership in Organizations. Fifth Edition, New Jersey: Prentice Hall Inc. 
M. Öner \& M. Onay \& İ. Deveci Kocakoç / Öğrencilerin Kariyer Planlamalarında Girişimcilik, Profesyonellik ve Liderlik Arzularının Ölçülmesi

EKLER: Ölçekte yer alan (gri vurgulu) ve çıkarılan sorular

\begin{tabular}{|c|c|c|c|c|c|}
\hline $\begin{array}{l}\text { MOTIVASYON ÖLÇEĞİ } \\
\text { Lütfen her bir durumu dikkatlice okuyarak yan tarafta belirtilmiş } \\
\text { olan skalaya uygun şeklide katıldıklarınızı ve katılmadıklarını } \\
\text { belirtiniz. }\end{array}$ & 言 & 咅 & 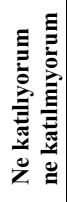 & 竞 & 焉 \\
\hline V0 Çok para kazanmanın en kolay ve hızı ıolu, kendi işimi kurmaktır. & (1) & (2) & (3) & (4) & (5) \\
\hline V1 Kendi alanımda uzmanlaşmak için çaba sarfeden bir kişiyim. & (1) & (2) & (3) & (4) & (5) \\
\hline $\begin{array}{l}\text { V2 Bir projenin /yada grubun başkanı olarak gösterildiğimde, böyle bir görevi } \\
\text { kabul etmek benim için bir şeref veya ayrıcalık olarak düşünürüm. }\end{array}$ & (1) & (2) & (3) & (4) & (5) \\
\hline $\begin{array}{l}\text { V3 Girişimci bir iş çevresinde çalışmanın, ebeveynlerimin beklentileri } \\
\text { açısından gerekli olduğunu düşünürüm. }\end{array}$ & (1) & (2) & (3) & (4) & (5) \\
\hline $\begin{array}{l}\text { V4 Kendi alanımda profesyonel olmaya odaklanırsam, mutlaka iyi bir hayatım } \\
\text { olur. }\end{array}$ & (1) & (2) & (3) & (4) & (5) \\
\hline $\begin{array}{l}\text { V5 Kişilik olarak daha çok takip eden birisi olduğum için, liderlik } \\
\text { sorumluluklarımı başkalarına devretmek beni mutlu eder. }\end{array}$ & (1) & (2) & (3) & (4) & (5) \\
\hline $\begin{array}{l}\text { V6 Bir işe başlamak ve o işi sürdürmenin getirdiği ödül ve tatmin, o işin } \\
\text { getireceği risklerden ve kayıplardan daha önemlidir. (ters kodlu) }\end{array}$ & (1) & (2) & (3) & (4) & (5) \\
\hline V7 Seçmiş olduğum alanda başarılı olmak, benim için bir ayrıcalık ve onurdur. & (1) & (2) & (3) & (4) & (5) \\
\hline $\begin{array}{l}\text { V8 Bir gruba liderlik yapmayı kabul ettiğim takdirde asla her hangi bir avantaj } \\
\text { veya özel fayda beklentisine girmem. }\end{array}$ & (1) & (2) & (3) & (4) & (5) \\
\hline $\begin{array}{l}\text { V9 Kendim için çalışmanın organizasyonların rutininden ve sertliğinden } \\
\text { kaçmanın en iyi yolu olduğunu düşünürüm. }\end{array}$ & (1) & (2) & (3) & (4) & (5) \\
\hline $\begin{array}{l}\text { V10 Ülkemin rekabetçiliğini artırmanın en iyi yolu, benim gibi insanların, } \\
\text { alanında çok yetenekli profesyoneller olmalarıdır. }\end{array}$ & (1) & (2) & (3) & (4) & (5) \\
\hline $\begin{array}{l}\text { V11 Bir grubun lideri olmak sadece benim için açık ve net avantajları olması } \\
\text { durumunda, ilgimi çeker. }\end{array}$ & (1) & (2) & (3) & (4) & (5) \\
\hline V12 Çocukluğumdan beri, kendi işimi kurmayı düşledim. (ters kodlu) & (1) & (2) & (3) & (4) & (5) \\
\hline $\begin{array}{l}\text { V13 Alanında yetenekli ve profesyonel olmak, çok miktarda maddi ve sosyal } \\
\text { statü ile sonuçlanmaz. }\end{array}$ & (1) & (2) & (3) & (4) & (5) \\
\hline V14 Grup üyeleri istedikleri takdirde, liderliği kabul ederim. (ters kodlu) & (1) & (2) & (3) & (4) & (5) \\
\hline $\begin{array}{l}\text { V15 Bu ülkenin daha çok girişimciliğe ihtiyacı vardır ve bende bunun } \\
\text { gerçekleşmesi için kendimi zorunlu hissediyorum. }\end{array}$ & (1) & (2) & (3) & (4) & (5) \\
\hline $\begin{array}{l}\text { V16 Kendi alanımda uzmanlaşmış bir profesyonel olmak, istikrarı bir geliri } \\
\text { sağlar. }\end{array}$ & (1) & (2) & (3) & (4) & (5) \\
\hline $\begin{array}{l}\text { V17 Bir projeden sorumlu olmak için yada liderlik yapmak için hiçbir ayrıcalık } \\
\text { beklemem. }\end{array}$ & (1) & (2) & (3) & (4) & (5) \\
\hline
\end{tabular}




\begin{tabular}{|c|c|c|c|c|c|}
\hline V18 Aile işletmesini devralmak için kuvvetli bir sorumluluğa sahibim. & (1) & (2) & (3) & (4) & (5) \\
\hline V19 Özel bir uzmanlık alanında tecrübe ve deneyim sahibi olmak isterim. & (1) & (2) & (3) & (4) & (5) \\
\hline V20 Her zaman liderlik yapmayı ve liderlik rollerini üstlenmekten zevk alırım. & (1) & (2) & (3) & (4) & (5) \\
\hline V21 Pazar için yeni ürün ve hizmetler yaratmayı düşünmekten hoşlanırım. & (1) & (2) & (3) & (4) & (5) \\
\hline $\begin{array}{l}\text { V22 Ebeveynim benim seçmiş olduğum uzmanlık alanında, çok yetenekli bir } \\
\text { profesyonel olacağımı ümit ederler. }\end{array}$ & (1) & (2) & (3) & (4) & (5) \\
\hline $\begin{array}{l}\text { V23 İnsanları etkileyen ve onları yönetmeyi her şeyden çok seven bir kişiliğe } \\
\text { sahibim. }\end{array}$ & (1) & (2) & (3) & (4) & (5) \\
\hline V24 Sürekli para kazanmakla ilgili fikirlere sahip olan bir kişiyim. & (1) & (2) & (3) & (4) & (5) \\
\hline $\begin{array}{l}\text { V25 Insanların bilgim, becerim ve tecrübelerimden dolayı bana bağlı } \\
\text { olmalarını severim. }\end{array}$ & (1) & (2) & (3) & (4) & (5) \\
\hline $\begin{array}{l}\text { V26 Benden istendiği takdirde, insanlara liderlik yapmam gerektiğini } \\
\text { düşünürüm. }\end{array}$ & (1) & (2) & (3) & (4) & (5) \\
\hline
\end{tabular}

\begin{tabular}{|c|c|c|c|c|c|}
\hline $\begin{array}{l}\text { NIYET ÖLÇEĞİ } \\
\text { Lütfen her bir durumu dikkatlice okuyarak yan tarafta belirtilmiş } \\
\text { olan skalaya uygun şeklide katıldıklarınızı ve katılmadıklarını } \\
\text { belirtiniz. }\end{array}$ & 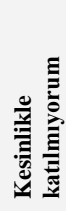 & 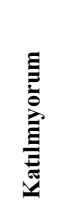 & 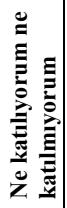 & 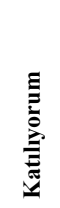 & 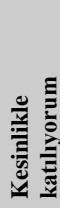 \\
\hline $\begin{array}{l}\text { V27 Tutarlı bir iş düşüncesi ile mezun olduktan sonra kendi işimi kurmaya } \\
\text { niyetliyim. }\end{array}$ & (1) & (2) & (3) & (4) & (5) \\
\hline $\begin{array}{l}\text { V28 Büyük ve istikrarlı bir organizasyonda uzman ve profesyonel olarak } \\
\text { kariyer yapmayı tercih ederim. }\end{array}$ & (1) & (2) & (3) & (4) & (5) \\
\hline V29 Gelecekte lider yada yönetici olmayı planlıyorum. & (1) & (2) & (3) & (4) & (5) \\
\hline $\begin{array}{l}\text { V30 Eğitimimden sonra mutlaka girişimci olacağım ve amacıma ulaşmak için } \\
\text { her şeyi yapmaya hazıım. }\end{array}$ & (1) & (2) & (3) & (4) & (5) \\
\hline $\begin{array}{l}\text { V31 İş hayatım boyunca uzmanlık, profesyonel ve teknik konularda daima } \\
\text { ilerlediğimi yada geliştiği görüyorum. }\end{array}$ & (1) & (2) & (3) & (4) & (5) \\
\hline $\begin{array}{l}\text { V32 Başlıca kariyer amacım, organizasyonlardaki insanların başında bulunan } \\
\text { lider ve yöneticileri yükseltmektir. }\end{array}$ & (1) & (2) & (3) & (4) & (5) \\
\hline $\begin{array}{l}\text { V33 Başlıca kariyer amacım; alanımda teknik uzman yada profesyonel } \\
\text { olmaktır. }\end{array}$ & (1) & (2) & (3) & (4) & (5) \\
\hline $\begin{array}{l}\text { V34 İlerideki iş yaşamımda, kendimi diğer çalışanların başında bir lider/ yada } \\
\text { yönetici olarak görmüyorum. }\end{array}$ & (1) & (2) & (3) & (4) & (5) \\
\hline V35 Mezun olduktan sonra bir profesyonel yada teknik uzman olarak kendimi & (1) & (2) & (3) & (4) & (5) \\
\hline
\end{tabular}




\begin{tabular}{|l|l|l|l|l|l|}
\hline \multicolumn{1}{|c|}{ görmüyorum. (ters kodlu) } & & & & & \\
\hline V36 Önümüzdeki beş yıl içinde kendi işimi kuracağım. (ters kodlu) & (1) & (2) & (3) & (4) & (5) \\
\hline V37 Önümüzdeki on yıl içinde, kendi işimi kuracağım. & (1) & (2) & (3) & (4) & (5) \\
\hline
\end{tabular}

\begin{tabular}{|c|c|c|c|c|c|}
\hline $\begin{array}{c}\text { ETKİNLİK ÖLÇEĞİ } \\
\text { Aşağıdaki görevleri başarıyla gerçekleştirmek için bu noktada } \\
\text { kendinizden ne kadar eminsiniz? Yanda belirtilen ifadelere göre } \\
\text { yanıt ölçeğindeki uygun numaraları işaretleyiniz. }\end{array}$ & $\begin{aligned} & \\
& 0 \\
& 0\end{aligned}$ & 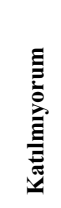 & 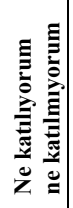 & 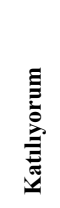 & 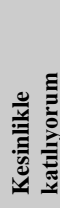 \\
\hline $\begin{array}{l}\text { V38 Piyasada ya da pazarda ihtiyaç olabilecek hizmetler hakkında fikirlere } \\
\text { sahip olmak }\end{array}$ & (1) & (2) & (3) & (4) & (5) \\
\hline $\begin{array}{l}\text { V39 Kendi uzmanlık alanımda en iyi uzman yada profesyonellerden birisi } \\
\text { olmak }\end{array}$ & (1) & (2) & (3) & (4) & (5) \\
\hline V40 Başkalarına ilham verecek vizyonu yaratmak & (1) & (2) & (3) & (4) & (5) \\
\hline $\begin{array}{l}\text { V41 iss planlamak (Pazar analizi, fiyatlandırma, finansal ve maliyet, pazarlama } \\
\text { ve satış) }\end{array}$ & (1) & (2) & (3) & (4) & (5) \\
\hline $\begin{array}{l}\text { V42 Kendi alanımda gelişen bilgi, beceri, uzmanlık yada profesyonelliği sürekli } \\
\text { izlemek }\end{array}$ & (1) & (2) & (3) & (4) & (5) \\
\hline V43 Ortak bir hedef için insanları bir araya getirmek ve desteklemek & (1) & (2) & (3) & (4) & (5) \\
\hline V44 İşimi destekleyecek ortakları yada bağlantı ağını kurmak & (1) & (2) & (3) & (4) & (5) \\
\hline $\begin{array}{l}\text { V45 Alanım ile ilgili uzmanlık, tecrübe ve bilgiyi başkalarına öğretmek veya } \\
\text { paylaşmak }\end{array}$ & (1) & (2) & (3) & (4) & (5) \\
\hline $\begin{array}{l}\text { V46 Benimle çalışan insanların yapabildiklerinden daha çoğunu yapmaları } \\
\text { konusunda motive etmek }\end{array}$ & (1) & (2) & (3) & (4) & (5) \\
\hline V47 Şirket yada firmanın performansını ve finansal kaynaklarını yönetmek & (1) & (2) & (3) & (4) & (5) \\
\hline V48 Kendi alanında daha çok ilerlemek için daha çok araştırma yapmak & (1) & (2) & (3) & (4) & (5) \\
\hline V49 Bir grup/ yada organizasyon için kararlar almak & (1) & (2) & (3) & (4) & (5) \\
\hline V50 Bir firmayı başlatmak ve onu büyütmek & (1) & (2) & (3) & (4) & (5) \\
\hline $\begin{array}{l}\text { V51 Profesyonel toplantılarda sunumlar yapmak, araştırma yada kitaplar } \\
\text { yazmak }\end{array}$ & (1) & (2) & (3) & (4) & (5) \\
\hline $\begin{array}{l}\text { V52 İnsanların ne yapmaları gerektiği konusunda planlamak, organize etmek } \\
\text { ve yönlendirmek }\end{array}$ & (1) & (2) & (3) & (4) & (5) \\
\hline V53 Tutarlı bir işe başlamak için fırsatları belirlemek & (1) & (2) & (3) & (4) & (5) \\
\hline V54 İnsanların daha çok çalışmalarını sağlamak için, ödül ve ceza yöntemini & (1) & (2) & (3) & (4) & (5) \\
\hline
\end{tabular}




\begin{tabular}{|l|l|l|l|l|l|}
\hline kullanmak & & & & & \\
\hline $\begin{array}{l}\text { V55 Yeni bir ürün yada hizmetin pazarlanmasında etkin bir kampanya } \\
\text { düzenlemek }\end{array}$ & (1) & (2) & (3) & (4) & (5) \\
\hline V56 Bir organizasyon için gelecekteki liderleri eğitmek ve geliştirmek & (1) & (2) & (3) & (4) & (5) \\
\hline
\end{tabular}

\section{SUMMARY}

Individuals strive to determine and achieve their goals and career plans earlier in their lives because of today's highly dynamic world environment. Students need to direct their education according to their plans for the future. They try to compensate the aspects that they think they lack of.

The main purpose of this study is to confirm EPL (Entrepreneurship, professionalism, and leadership) scale, which is developed by Chan et.al. (2012), for Turkish students. EPL scale measures students' tendencies towards these components (Entrepreneurship, professionalism, and leadership) based on their motivation, efficacy, and intent. Scale is used by the consent of Kim Yin Chan. First, the scale is translated into Turkish. Results of the surveys are computed in terms of sums of scores as told by the evaluation scheme given by Chan. These summed scores are used in all analyses. EPL scale is composed of three main factors, namely motivation, intent, and efficacy. Each main factor has three subfactors: Entrepreneurship, professionalism, and leadership. By a survey study on 903 of Manisa Celal Bayar University students, original EPL scale is examined by second order confirmatory factor analysis (CFA) and re-designed to fit Turkish students.

Some questions in the original scale are eliminated because of poor fit to our sample, but the factor structure remained the same. For both the first and the second level CFA, fit indices are acceptable. For the first level CFA (the relationship between items and sub-factors), all items are loaded with high scores, however the model is very complicated to interpret. For the second level CFA (the relationship between sub-factors and factors), all coefficients are very high. For motivation, professionalism has the highest coefficient while for intent, leadership has the highest one. For efficacy, both professionalism and leadership have the highest coefficient. All sub-factors also have significant correlations.

If a student makes plans about future and tries to determine his career targets, he needs to know his personal traits, strong and weak points very well and he needs to tend to subjects that are beneficial to him for his purposes. He also needs to do this as early as possible in his school life. EPL scale evaluates students for this purpose and is still in development. Adaptation of this scale for Turkish students is therefore important. By this study, introduction of the scale to Turkish literature and a limited confirmation of the scale are aimed. 
The following inferences can be made by the results of this study:

1. As motivation of the students gets higher, their intent to develop professionalism, leadership and entrepreneurship characteristics will be higher.

2. As motivation of the students gets higher, they will feel themselves more efficient and make more result oriented studies.

3. As students' intent to develop professionalism, leadership and entrepreneurship characteristics gets higher, they will see themselves more efficient, more self-confident and self-conscious.

The results of the research demonstrate the positive effects of the development of three basic personal and managerial skills (entrepreneurship, professionalism and leadership) that influence the lives of university students in terms of their career planning. 